\title{
EXAMINATION OF THE SELF STRUCTURE, INTERPERSONAL INFLUENCE, TRUST AND BRAND ATTITUDE AS ANTECEDENTS OF THE EMOTIONAL BRAND ATTACHMENT
}

\author{
*Aysel ERCIS (Orcid Id: 0000-0002-9835-8574) \\ **Tugba YILDIZ (Orcid Id: 0000-0003-0260-0555) \\ *** Bahar TURK (Orcid Id: 0000-0001-9590-769X) \\ * Atatürk University \\ **Bayburt University \\ ***Ondokuz Mayls University
}

\begin{abstract}
Consumers who have emotional brand attachment define brands as more attractive and more distinctive. Consumers who perceive high brand attractiveness and think that the brand should be differentiated from other brands will be loyal customers of the brand. Moreover, they will tend to advocate to enable the brand to be recommended by the mouth-to-mouth communication channel. It is a success that cannot be achieved in any other environment. Therefore, it is very important to identify the motivations that enable individuals to establish emotional ties with brands. In this context, regarding the brand, the attitude and trust variables, which are thought to have a direct influence on emotional brand attachment are discussed in this study. Susceptibility to interpersonal influence, which indirectly affects emotional brand attachment and directly affects the attitude and trust variables regarding the brand and again the concept "self" that affects this variable were examined within the scope of the study. The research model formed was tested with structural equation analysis; it was found that the self-structure affects the susceptibility to interpersonal influence, that the interpersonal influence affects the attitude and trust towards the brand, and that all these variables have a significant effect on the emotional brand attachment.
\end{abstract}

Keywords: Self Structure, Interpersonal Influence, Emotional Brand Attachment

\section{INTRODUCTION}

Today, building emotional brand attachment is one of the most important issues for businesses from all sectors (Malär et al., 2011). Brands that can establish emotional bonds with their customers can express their core values (Berry, 2000), thus ensuring loyalty and therefore profitability (Grisaffe and Nguyen, 2011).

Consumers are so attached to some brands that an emotional attachment develops between them (Bouhlel et al., 2011). Emotional commitment plays an important role in establishing long-term relationships and maintaining attachment. In the process of creating emotional attachment, gaining consumer trust is important (Levy and Hino, 2016). In this context, there is a positive relationship between creating a sense of trust in people and social influence (Doney et al., 2007). Similarly, there is a positive relationship between people's attitudes and emotions (Sukhu et al., 2019). Additionally, interpersonal influence plays an important role in shaping the decisions of consumers (Mourali et al., 2005). On the other hand, the individual's self-structure affects his distance to interpersonal influence. In other words, the increase of the individual's independent self-structure rises the distance to the influence. Self-structure affects their behavior in interpersonal influence (Holland et al., 2004).

Besides, firms see it as the only solution for establishing emotional consumer-brand attachment to make their brands distinctive in a competitive environment (Akgün et al., 2013). In this way, they assume that their brands will be repurchased by consumers. Emotional brand loyalty is important for repurchases therefore marketers need to know the antecedent of this variable that can be managed or controlled. In this context, it is necessary to investigate the factors that are needed to establish emotional brand attachment and to identify important precursors (Grisaffe and Nguyen, 2011).

The researches conducted reveal that many variables are effective in the emotional brand attachment (Bouhlel et al., 2011, Levy and Hino, 2016). The results obtained from these studies show that individuals 
who have positive attitudes towards the brand and trust in the brand (Levy and Hino, 2016) develop emotional brand attachment (Sukhu et al., 2019). Besides, studies reveal that interpersonal influence affects consumers' decision-making mechanisms (Mourali et al., 2005) and that it has a positive influence on individuals' developing a positive attitude towards the brand and trusting in the brand (Doney et al., 2007, Uddin and Khan, 2018, Thurasamy et al., 2002). In addition to all these, the self-structure that affects sensitivity to interpersonal influence should also be considered. It is seen that the distance of individuals with independent self-structure to interaction has been increasing (Holland et al., 2004).

Within the scope of this information, in this research where the aim is to investigate the primary forces of emotional brand attachment, the effect of brand trust and attitude towards the brand on emotional brand attachment was examined, also considering the related literature support. Also, the effect of interpersonal influence on brand trust and attitude towards the brand was discussed and finally, the effect of an individual's self-structure on interpersonal influence was investigated

\section{LITERATURE REVIEW AND THEORETICAL FRAMEWORK Self Structure}

It is known that there is a relationship between the brand preferences and selves of individuals who meet the need to express themselves with brands (Escalas and Bettman, 2005). Because individuals tend to prefer products that are compatible with them. In the related literature, the self-structure is considered as two variables as "interdependent self" and "independent self". The basic principle of the dependent self structure is based on the connection of the individual with other individuals. Individuals tend to think and act in such a way as to emphasize their connections with others and strengthen their existing relationships to maintain and develop this structure based on interdependence (Cross et al., 2000). Interdependent self structure means that one sees him/herself as an individualized being or as someone who thinks $\mathrm{s} / \mathrm{he}$ is related to others. Therefore, it is stated that there is an interaction between the dependent self structure and susceptibility to interpersonal influence (Sun et al., 2009). Individuals who have an independent self structure see themselves as unique and different from group members and think that they have valuable features (Agrawal and Maheswaran, 2005). While individuals with interdependent self structure tend to make choices according to functional benefits, it is seen that individuals with independent self structure make product choices by considering symbolic benefits (Başar and Erciş, 2015).

H1: The self-structure of consumers affects their tendency to interpersonal influence.

H1a: The interdependent self-structure of consumers affects their tendency to interpersonal influence.

H1b: The independent self-structure of consumers affects their tendency to interpersonal influence

\section{Interpersonal Influence}

In the literature, sensitivity to interpersonal influence is treated in two categories. The first one is informational interpersonal influence and the other is prescriptive interpersonal influence (Bearden et al., 1989). Informational interpersonal influence is described as "the interaction regarding the acceptance of information based on evidence of truth" (Deutsch and Gerard, 1955). "The impact formed to adapt to the expectations of other individuals," defines normative interpersonal influence. Informational affect both indicates accepting information and having a good tendency to purchase and proving the truth reliably (Saleem and Ellahi, 2017). The normative interpersonal influence reflects the psychological needs of individuals to comply with group norms and standards to be accepted by the group concerned (Shen et al., 2010, Wang et al., 2005). Normative sensitivity is also related to the social effects that result from wanting to look good in the face of other individuals (Hoon Ang et al., 2001, Girma, 2016). Therefore, predisposition to interpersonal influence affects people's generally accepted behaviors, thoughts and beliefs about products (Alkailani and Kumar, 2016). The sensitivity of consumers to interpersonal influence especially indicates their degree of being influenced by others in their consumption preferences (Kropp et al., 2003). In other words, to which extent the information obtained from the society affects consumers depends on their sensitivity to interpersonal interaction (Hoffmann and Broekhuizen, 2009, Chen et al., 2005).

H2: The tendency of consumers to interpersonal influence affects brand trust.

H3: The tendency of consumers to interpersonal influence affects the attitude towards the brand. 


\section{Brand Trust}

The consumer belief developed regarding the brand's being honest and trustworthy is defined as brand trust (Chatterjee and Chaudhuri, 2005: 2). In other words, the customer's willingness to rely on the brand's ability to perform can be explained as brand trust (Chaudhuri and Holbrook, 2001). The most important point in the context of consumer-brand relationships is trust in the brand (Ulusu, 2011). Trust in a brand also means that consumers are willing to trust against the risk because of their expectations that the brand will lead to positive results (Lau and Lee, 1999: 344). Customers who are satisfied with the brand can turn to the same brand when they need it, and this situation strengthens the relationship in time. As a result of this strong relationship, emotional attachment is formed. In addition, with the emotional attachment formed, the customer becomes unable to think of other brands since s/he starts to see the brand as a friend (Sağlam and Sağlam, 2016). However, the phenomena of trust in the brand and satisfaction are highly effective in the formation of emotional attachment (Chinomona, 2013, Esch et al., 2006). According to Frasquet et al. (2017), as brand trust increases, brand loyalty also increases, that is trust in the brand affects loyalty positively (Bouhlel et al., 2011).

H4: Trust in the brand affects emotional attachment.

\section{Attitude towards Brand}

Attitude is a reactive predisposition that an individual has regarding anything around him. The subject of attitude may be concrete entities or abstract concepts. Besides, determining the attitudes of individuals is important in terms of predicting their behavior (Göksu, 2007: 87). Attitudes develop over time through the learning process and are shaped by the knowledge and experience an individual obtains from his/her family and the social groups to which s/he belongs to or wants to belong to (Fandos and Flavian, 2006). The attitude towards the brand can be expressed as an individual's internal assessment of the brand (Mitchell and Olson, 1981). According to Chung et al., (2013), the attitude towards the brand consists of the positive/negative evaluations of the customers regarding the brand. All these reveal that there is a positive relationship between an individual's attitudes towards the brand and his/her attachment to the brand (Chen et al., 2017).

Consumers who are emotionally attached to a brand, expected to have a positive attitude towards this brand. Although, positive brand attitudes are often reflected in powerful emotional attachments, here are several critical points. Firstly, strong emotional attachments develop over time and are often based on the influence between an individual and an attachment object/brand (Baldwin et al., 1996). These influences stimulate the development of meaning and evoke strong emotions about the attachment object/brand. Attitudes reflect one's evaluative reactions to an object. These reactions can evolve without any direct contact with them. Thus, a consumer may have a positive attitude toward an object/brand without ever having had any experience with it at all (Thomson et al., 2005). The other one, consumers can have positive attitudes toward any brand and toward objects that have little importance to their life. The brands to which consumers are emotionally attached are few. Because of this, this attachment is generally regarded as profound and meaningful (Richins, 1994). Also, individuals who are strongly emotionally attached to brands and show specific behaviors such as affinity maintenance and separation distress. Finally, individuals who are strongly attached to a person or brand are mostly committed to protecting their relationship with it (Miller, 1997, Thomson et al., 2005).

H5: The attitude towards the brand affects emotional attachment.

\section{Emotional Brand Attachment}

Emotions refer to responses given to a stimulus that is usually more intense, has a long-term effect and the reason for which is definite (Deniz and Erciş, 2010: 146). It is not enough to act solely on performance to create a big brand. Because consumers are living in an emotional world. In other words, the emotions of the individual have an important place in decision making (Webber, 1997). In addition to the ultimate solution is to create emotional linkages in a competitive environment in which companies try to differentiate their brands from others. In this way, brands strive to build deep, long-term, strong ties with their customers (Akgün et al., 2013). Identifying the variables that can strengthen emotional brand attachment both improves brand equity and enables more durable relationships (Krohmer et al., 2009). For this reason, it is very important to observe/know the emotional reactions of individuals towards brands to create consumers who show emotional brand attachment. Consumers' usage time of brands may 
vary. While some consumers use a brand only once for reasons such as poor quality, lack of functionality, overpricing or poor experience, some consumers can approach a particular brand lovingly and continue to prefer it despite all its costs. It is possible to say that the consumers who continue to buy the same brand for a long time develop emotional loyalty for that brand and even become the strong supporters of these brands they are emotionally connected to (Cheong, 2013). On the other hand, when we consider that there are many brands around consumers today, that brands have become a part of our lives, managers inevitably tend to adopt addictive marketing strategies that render their brands adorable (Pourazad and Pare, 2014). In other words, brand managers who know that the emotional dimension of the consumerbrand relationship has a great impact on consumer behaviors are attachment to creating passionate brands (Bauer, et al., 2007). On the other hand, some researchers view attachment as a measure of marketing effectiveness. In a marketing context, a suitable indicator of attachment is the extent to which the individual remains loyal to the brand (Garbarino and Johnson, 1999). In other words, the strength of emotional attachment to an object/brand may be associated with an investment in the object/brand, that is, the willingness to renounce self-interest to promote a relationship. Briefly, a valid measure of emotional attachment should predict consumers' investment in a brand (Thomson et al., 2005).

\section{RESEARCH METHOD}

\section{Purpose, Scope, and Limitations of the Research}

It is important to establish emotional bonds with the consumers to establish long-term relationships with them and to strengthen the relationship. Therefore, it is necessary to determine which variables are effective for brands to establish emotional attachment with their customers. In this context, regarding the brand, the attitude and trust variables, which are thought to have a direct influence on emotional brand attachment are discussed in this study. Susceptibility to interpersonal influence, which indirectly affects emotional brand attachment and directly affects the attitude and trust variables regarding the brand and again the concept "self" that affects this variable were examined within the scope of the study. In this study, the issue treated is the mobile phone market, which is a sector that has been growing day by day, in which competition has been increasing and it has become hard to convince the consumer and even forming emotional attachment and retaining the consumer is seen as the main solution. Therefore, the results obtained are not inclusive for people who do not use mobile phones. Besides, the results are limited only to the sample in which data is collected for this study and cannot be generalized for other product groups, brands, and cities.

\section{Data Collection Method and Process}

The main population of the research consists of individuals using mobile phones and aged 18 years and older living in Erzurum. The research data were obtained by using face to face survey method. The convenience sampling method was preferred as the sampling method. All of the scales used in the study were taken from the studies in the literature and the statements were adapted in line with the purpose of the research.

The self-structure scale was obtained from the study of Singelis (1994) and comprised of twenty fouritem Likert type scale. The interpersonal influence scale was obtained from the study of Bearden et al., (1989) and comprised of twelve items Likert type scale. Attitude towards the brand scale was obtained from the research of Eshgi et al., (2017) and comprised of quinary semantic differential scales. In the brand trust scale, the study conducted by Chinomona (2016) and comprised of four items Likert type scale. Emotional brand attachment scale Thomson's (2005) study was utilized and comprised of a tenitem Likert type scale.

The translation of the scales was made by the language experts and the mistakes that could arise by using the translation-back translation method were tried to be minimized. A pilot scheme was applied to a sample of 20 people and the survey was finalized. The survey was conducted between 18.07.2019 and 25.08.2019. After the surveys filled wrongly and incompletely were eliminated 326 surveys were evaluated. In the analysis of the data, descriptive statistics, explanatory and confirmatory factor analysis and structural equation modeling were utilized by using SPSS 22 and AMOS 22 package programs. 


\section{Research Model}

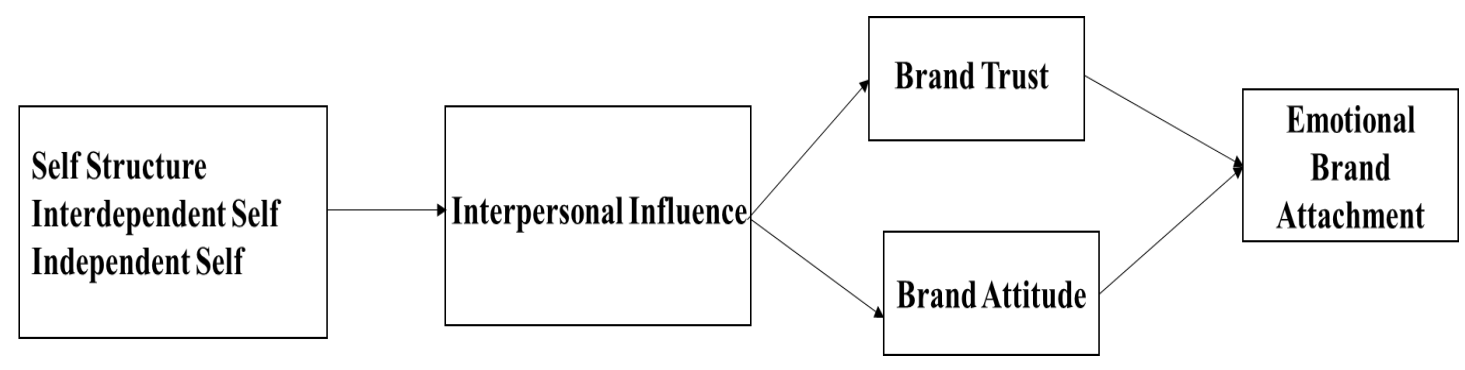

Figure 1. Research Model

\section{FINDINGS}

\section{Demographic Characteristics of Respondents}

It was determined that most of the participants were males $(60 \%)$, be in $18-28$ age range $(65 \%)$, single (67\%), have an income of 2001-3000 TL (28\%), be university graduates (57\%), and private-sector employees (29\%).

\section{Explanatory and Confirmatory Factor Analysis}

For the scale dimensions used in the research to be determined clearly, Explanatory Factor analysis was made. In the analysis in which the structural validity of the scales was tested, factor loads of 0.40 and above were considered (Nakip, 2006) and it was found that 2 expressions of sensitivity and 5 expressions of self were eliminated because the factor loads were lower than the reference value. Obtained factors explained $61.7 \%$ of the total variance. The KMO sample qualification criteria were found to be $89 \%$, Bartlett Sphericity Test 10571.774 and Degree of Freedom 1128. It was determined that factor loadings of the self-variable vary between $0.48-0.70$ for the interdependent self, $0.54-0.76$ for the independent self, 0.44-0.74 for sensitivity to informational effect in the variable of susceptibility to interpersonal influence, 0.54-0.75 for sensitivity to normative effect, $0.58-0.71$ for the brand trust variable, $0.63-0.78$ for the attitude towards the brand, $0.79-0.88$ for the affection in the variable of emotional brand attachment, 0.83 0.85 for connection and $0.77-0.83$ for passion.

The reliability coefficients (Cronbach's alpha) of the scales used were measured as 0.84 for the Self Structure, 0.85 for Interpersonal Influence, 0.90 for Brand Trust, 0.91 for Attitude Towards the Brand and 0.97 for Emotional Brand Attachment. Before testing the model, it was checked whether there was multicollinearity between the variables; VIF values in the range of 1.078 to 1.497 and the tolerance values in the range of 0.666 to 0.927 was seen to be in the range, it was accepted that no multi-connection problem (Hair et al., 1998). Also, when the relationship between error terms (autocorrelation) is examined, it is seen that the Durbin-Watson test result is 1,645 and this value is in the range of 1-3 accepted as the general criterion, no autocorrelation was found in the analysis.

After the exploratory factor analysis, Confirmatory Factor Analysis was performed to test the measurement model. As a result of the analysis, it was seen that the expressions had acceptable compliance values. fit indexes are as follows: $\mathrm{CMIN} / \mathrm{df}=1.62 ; \mathrm{RMSEA}=0.04 ; \mathrm{RMR}=0.09 ; \mathrm{AGFI}=0.90$; $\mathrm{GFI}=0.93 ; \mathrm{NFI}=0.95 ; \mathrm{CFI}=0.94$

Table 01. CR and AVE values of the scales

\begin{tabular}{|l|c|c|}
\hline \multicolumn{1}{|c|}{ Variables } & CR & AVE \\
\hline Interdependent Self & 0,747 & 0,507 \\
\hline Independent Self & 0,763 & 0,518 \\
\hline Normative & 0,822 & 0,539 \\
\hline Informational & 0,779 & 0,542 \\
\hline Brand Trust & 0,870 & 0,629 \\
\hline Attitude towards Brand & 0,882 & 0,601 \\
\hline Affection & 0,944 & 0,810 \\
\hline Connection & 0,905 & 0,760 \\
\hline Passion & 0,910 & 0,772 \\
\hline
\end{tabular}


Table 2. Results of Confirmatory Factor Analysis of Scales

\begin{tabular}{|c|c|c|c|c|c|}
\hline Variables & $\begin{array}{l}\text { Standardized } \\
\text { Coefficients } \\
\end{array}$ & $\begin{array}{l}\text { Error } \\
\text { Variances }\end{array}$ & $\begin{array}{l}\text { (t) } \\
\text { Value }\end{array}$ & $\mathbf{P}$ & $\mathbf{R}^{2}$ \\
\hline \multicolumn{6}{|l|}{ Interdependent self-structure } \\
\hline $\begin{array}{l}\text { If my brother or sister fails, I feel } \\
\text { responsible. }\end{array}$ & 0,628 &, 139 & 8,013 & $* * *$ & 0,395 \\
\hline $\begin{array}{l}\text { I will stay in a group if they need } \\
\text { me even when I'm not happy with } \\
\text { the group. }\end{array}$ & 0,627 &, 134 & 8,054 & $* * *$ & 0,393 \\
\hline $\begin{array}{l}\text { It is important to me to respect } \\
\text { decisions made by the group. }\end{array}$ & 0,617 &, 158 & 7,849 & $* * *$ & 0,381 \\
\hline $\begin{array}{l}\text { I should take into consideration my } \\
\text { parents advice when making } \\
\text { educationlcareer plans }\end{array}$ & 0,522 &, 146 & 7,139 & $* * *$ & 0,273 \\
\hline $\begin{array}{l}\text { I often have the feeling that my } \\
\text { relationships with others are more } \\
\text { important } \\
\text { accomplishments }\end{array}$ & 0,586 &, 152 & 7,057 & $* * *$ & 0,344 \\
\hline $\begin{array}{l}\text { I will sacrifice my self-interest for } \\
\text { the benefit of the group I am in }\end{array}$ & 0,642 &, 147 & 8,090 & $* * *$ & 0,412 \\
\hline $\begin{array}{l}\text { I respect people who are modest } \\
\text { about themselves. }\end{array}$ & 0,475 &, 137 & 6,773 & $* * *$ & 0,225 \\
\hline $\begin{array}{l}\text { I would offer my seat in a bus to } \\
\text { my professor. }\end{array}$ & 0,591 &, 146 & 7,700 & $* * *$ & 0,350 \\
\hline $\begin{array}{l}\text { My happiness depends on the } \\
\text { happiness of those around me. }\end{array}$ & 0,677 &, 140 & 8,319 & $* * *$ & 0,458 \\
\hline $\begin{array}{l}\text { It is important for me to maintain } \\
\text { harmony within my group. }\end{array}$ & 0,553 &, 138 & 7,370 & $* * *$ & 0,306 \\
\hline $\begin{array}{l}\text { I have respect for the authority } \\
\text { figures with whom I interact }\end{array}$ & 0,516 & & & $* * *$ & 0,266 \\
\hline \multicolumn{6}{|l|}{ Independent self-structure } \\
\hline $\begin{array}{l}\text { I value being in good health above } \\
\text { everything }\end{array}$ & 0,681 &, 094 & 10,545 & $* * *$ & 0,464 \\
\hline $\begin{array}{l}\text { I prefer to be direct and forthright } \\
\text { when dealing with people I've just } \\
\text { met }\end{array}$ & 0,568 &, 094 & 9,013 & $* * *$ & 0,323 \\
\hline $\begin{array}{l}\text { Being able to take care of myself is } \\
\text { a primary concern for me. }\end{array}$ & 0,619 &, 094 & 9,735 & $* * *$ & 0,383 \\
\hline $\begin{array}{l}\text { I am the same person at home that I } \\
\text { am at school }\end{array}$ & 0,512 &, 093 & 8,224 & $* * *$ & 0,262 \\
\hline $\begin{array}{l}\text { I am comfortable with being } \\
\text { singled out for praise or rewards }\end{array}$ & 0,627 &, 093 & 9,892 & $* * *$ & 0,393 \\
\hline $\begin{array}{l}\text { Having a lively imagination is } \\
\text { important to me }\end{array}$ & 0,703 & & & $* * *$ & 0,494 \\
\hline \multicolumn{6}{|l|}{ Interpersonal influence } \\
\hline $\begin{array}{l}\text { When buying products, I generally } \\
\text { purchase those brands that I think } \\
\text { others will approve of. }\end{array}$ & 0,327 &, 110 & 6,463 & $* * *$ & 0,407 \\
\hline $\begin{array}{l}\text { If other people can see me using a } \\
\text { product, I often purchase the brand } \\
\text { they expect me to buy }\end{array}$ & 0,472 & & & $* * *$ & 0,223 \\
\hline $\begin{array}{l}\text { I achieve a sense of belonging ing } \\
\text { by purchasing the same products } \\
\text { and brands that others purchase }\end{array}$ & 0,803 &, 221 & 8,792 & $* * *$ & 0,645 \\
\hline $\begin{array}{l}\text { If I want to be like someone, I often } \\
\text { try to buy the same brands that they } \\
\text { buy. }\end{array}$ & 0,654 &, 231 & 6,954 & $* * *$ & 0,528 \\
\hline $\begin{array}{l}\text { I often identify with other people } \\
\text { by purchasing the same products } \\
\text { and brands they purchase. }\end{array}$ & 0,717 &, 215 & 8,241 & $* * *$ & 0,514 \\
\hline $\begin{array}{l}\text { I frequently gather information } \\
\text { from friends or family about a } \\
\text { product before I buy it. }\end{array}$ & 0,641 &, 087 & 10,559 & *** & 0,411 \\
\hline $\begin{array}{l}\text { If I have a little experience with a } \\
\text { product, I often ask my friends } \\
\text { about the product. }\end{array}$ & 0,831 &, 090 & 12,029 & $* * *$ & 0,691 \\
\hline To make sure I buy the right & 0,741 & & & $* * *$ & 0,549 \\
\hline
\end{tabular}




\begin{tabular}{|c|c|c|c|c|c|}
\hline Variables & $\begin{array}{l}\text { Standardized } \\
\text { Coefficients }\end{array}$ & $\begin{array}{l}\text { Error } \\
\text { Variances }\end{array}$ & $\begin{array}{l}\text { (t) } \\
\text { Value }\end{array}$ & $\mathbf{P}$ & $\mathbf{R}^{2}$ \\
\hline \multicolumn{6}{|l|}{$\begin{array}{l}\text { product or brand, I often observe } \\
\text { what others are buying and using }\end{array}$} \\
\hline \multicolumn{6}{|l|}{ Brand Trust } \\
\hline I rely on this brand & 0,788 & & & $* * *$ & 0,621 \\
\hline I trust this brand. & 0,932 & 0,058 & 18,489 & $* * *$ & 0,869 \\
\hline This is an honest brand. & 0,801 & 0,058 & 15,786 & $* * *$ & 0,641 \\
\hline This brand is safe. & 0,756 & 0,060 & 14,643 & $* * *$ & 0,571 \\
\hline \multicolumn{6}{|l|}{ Brand Attitude } \\
\hline Unfavorable $\backslash$ Favorable & 0,767 & & & $* * *$ & 0,588 \\
\hline Unlikeable\Likeable & 0,863 & 0,071 & 14,528 & $* * *$ & 0,745 \\
\hline Unpleasant|Pleasant & 0,860 & 0,068 & 16,582 & $* * *$ & 0,739 \\
\hline Bad/Good & 0,780 & 0,069 & 16,507 & $* * *$ & 0,609 \\
\hline Unappealing/Appealing & 0,774 & 0,060 & 17,374 & $* * *$ & 0,599 \\
\hline \multicolumn{6}{|l|}{ Emotional Brand Attachment } \\
\hline Loved & 0,857 & & & & 0,735 \\
\hline Friendly & 0,923 & 0,035 & 28,055 & $* * *$ & 0,852 \\
\hline Affectionate & 0,948 & 0,042 & 24,999 & $* * *$ & 0,898 \\
\hline Peaceful & 0,888 & 0,044 & 21,997 & $* * *$ & 0,788 \\
\hline Attached & 0,866 & & & & 0,749 \\
\hline Bonded & 0,895 & 0,045 & 23,063 & $* * *$ & 0,800 \\
\hline Connected & 0,893 & 0,045 & 22,874 & $* * *$ & 0,798 \\
\hline Passionate & 0,910 & & & $* * *$ & 0,828 \\
\hline Delighted & 0,831 & 0,041 & 21,356 & $* * *$ & 0,690 \\
\hline Captivated & 0,903 & 0,040 & 25,606 & $* * *$ & 0,815 \\
\hline
\end{tabular}

The results of the confirmatory factor analysis showed that the dimensions were reliable. Therefore, the results confirm the factor structure of the scale. The research model formed behind factor analyses was tested with structural equation analysis. The structural model, statistical values and model fit indexes obtained as a result of the analysis are as shown below.

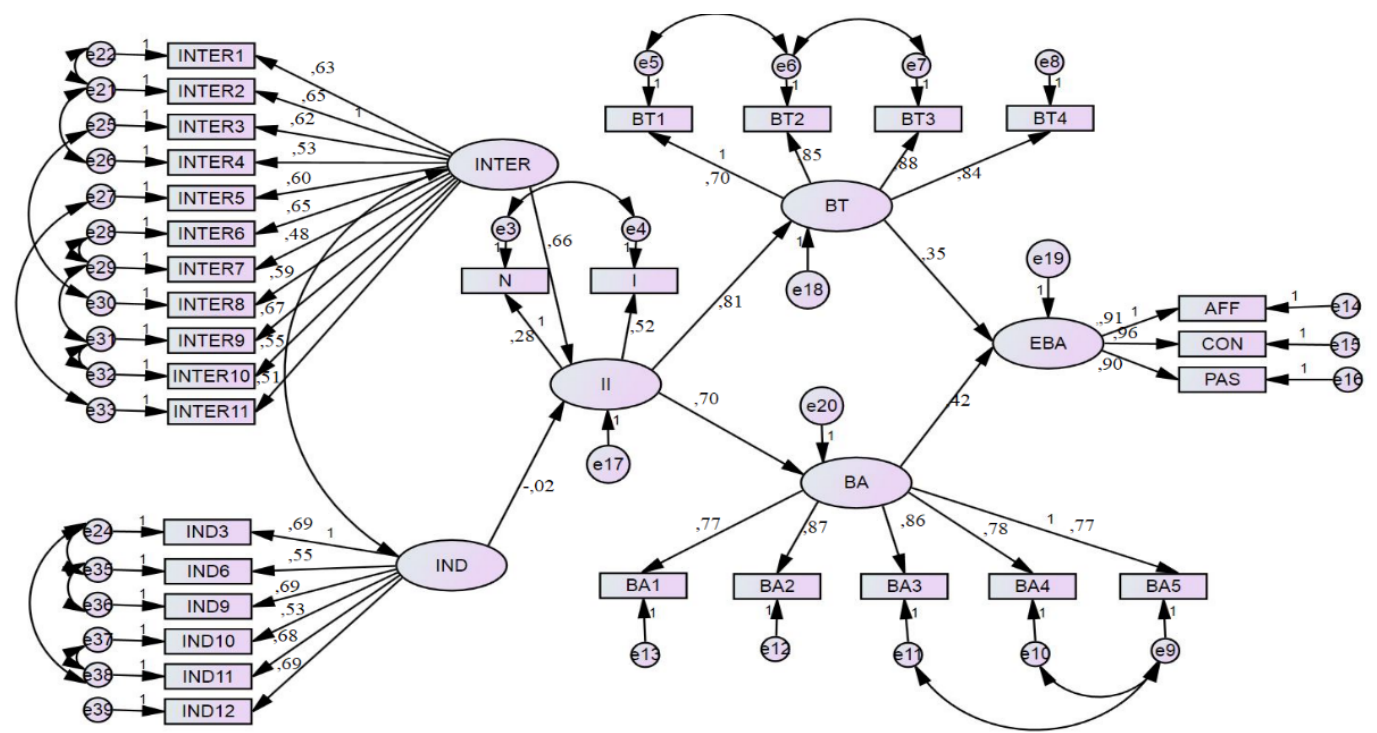

Figure 2. Structural Model

Key: INTER: Interdependent Self, IND: Independent Self, II: Interpersonal Influence, N: Normative, I: Informational, BT: Brand Trust, BA: Brand Attitude, EBA: Emotional Brand Atttachment, AFF: Affection, CON: Connection, PAS: Passion

$\boldsymbol{X}^{2}$ /sd: 1,63, RMSEA: 0.04, RMR: 0.10, AGFI: 0.91, NFI: 0.94, CFI: 0.95, GFI: 0.90. 
Tablo 3. Results of the Research Models

\begin{tabular}{|l|c|c|l|l|l|}
\hline Statistically Important Paths & $\begin{array}{l}\text { Standardized } \\
\text { Coefficients }\end{array}$ & Error Variances & $\begin{array}{l}\text { (t) } \\
\text { Values }\end{array}$ & $\mathbf{P}^{*}$ & $\mathbf{R}^{\mathbf{2}}$ \\
\hline Interdependent Self Benlik $\rightarrow$ Interpersonal &, 663 &, 058 & 3,986 & $* * *$ &, 431 \\
\hline Independent Self $\rightarrow$ Interpersonal Influences &,- 020 &, 022 &,- 303 &, 762 & \\
\hline Interpersonal Influence $\rightarrow$ Brand Trust &, 810 &, 647 & 4,221 & $* * *$ &, 655 \\
\hline Interpersonal Influence $\rightarrow$ Attitude towards Brand &, 700 &, 600 & 4,227 & $* * *$ &, 490 \\
\hline Attitude towards Brand $\rightarrow$ Emotional Brand &, 417 &, 110 & 6,775 & $* * *$ &, 465 \\
\hline Brand Trust $\rightarrow$ Emotional Brand Attachment &, 353 &, 120 & 5,654 & $* * *$ & \\
\hline
\end{tabular}

$* * p<0.01$

As shown in Figure 1 and Table 3, the path coefficients and model fit values of the variables are within acceptable limits and significant. The values obtained were improved by covariances drawn between the error terms after the modification suggestions. In this context, it was observed that brand attitude and brand trust variables are observed to affect emotional brand attachment (H4, H5). Besides, it is understood that interpersonal influence affects brand trust (H2) and attitude towards the brand (H3). Interdependent self, which is one of the sub-dimensions of the self variable has a significant effect on interpersonal influence (H1a) and that independent self does not have have a significant effect (H1b). Besides, this result coincides with the current literature. In this case, the H1 hypothesis, which is considered as one of the sub-hypotheses and which states that the self has a significant effect on interpersonal influence, was accepted.

\section{CONCLUSION AND DISCUSSIONS}

The research model, which combines the variables of brand trust and attitude, sensitivity to interpersonal interaction and self-structure, which are determined to affect emotional brand loyalty was tested; the following results were obtained and the conclusions are summarized as a theoretically and practically:

As a result of the analysis, it was found that brand trust affected emotional brand attachment. In other words, an individual can develop an emotional attachment to the brands' trusts (Japutra et al., 2014, Vlachos et al., 2010). Trust in the brand is perceived as an important factor in an individual's thinking that the brand is interested in him/her, in his/her establishing a healthy relationship with the brand including attachment and even in the formation of a passionate interaction. Individuals' belief that the brand will fulfill its promises, their trust in the brand's sincerity will strengthen their relationship with the brand and ensure the surfacing of positive emotions. Another result is that the attitude towards the brand affects the emotional brand attachment. In other words, attitudes have a positive effect on people's emotions (Shiong, 2019). The positive thoughts of customers regarding the brand is an effective factor in their establishing emotional attachment. That the brand has attractive, tasteful designs and pleasant looks will increase the positive emotions in the consumer. According to the findings, interpersonal influence affects both attitudes towards brand attitude and trust (Hoon Ang et al., 2001). Khare (2014) stated that there is a positive relationship between attitude and interpersonal interaction. Besides, the element of trust, which is an integral part of successful relationships, is influenced by the indirectly acquired information exchange (Zaroli, et al., 2017). McAllister (1995) stated that the frequency of interaction affects trust. The results obtained are consistent with the results expressed in the related literature. Factors that can be the driving force for the variables of trust and attitude that are necessary to establish the emotional attachment that expresses the way to establish pleasant, passionate, loving and friendly intimacy with the customers should be considered. In other words, it is important to gain the trust of the customer and to know the variables that will create a positive attitude in them. At this point, we encounter social norms and information flow. Throughout the process of the individual's developing trust in the brand, the thoughts of other individuals around him/her give clues. The individual who exchanges information with others collects information about the product and tries to capture the sense of a reliable brand by actually avoiding risk. Furthermore, the individual who thinks s/he will like the brand that other people will buy tends to find that brand much more attractive and enjoyable.

Finally, the individual's self-structure is effective in his/her susceptibility to interpersonal influence. Owned self-structure affects their relationships with other people (Cross and Madson, 1997, Gardner et al., 1999). Whether a person has an interdependent or independent self-structure determines his/her response to the interaction. Accordingly, while individuals with interdependent self-structure show sensitivity to interpersonal interaction, individuals with independent self-structure do not. Because while 
individuals who have interdependent selves act as collectivists, those who have independent selves think individually (Markus and Kitayama, 1991). Individuals who try to maintain harmony within the group they are in or individuals who associate happiness with the happiness of the people around them show sensitivity to interaction. Accordingly, people who consider the advice of the ones around them are careful about what other people buy while choosing products. By acting in this way, they do not break their connections with them and taste the sense of belonging. It is aimed to fully understand the customer together with treating the concept of self as the precursor of the interaction that affects the emergence of brand trust and attitude in creating emotional brand attachment. It is clear that to address the emotions of the individual, we need to know him/her very well. The researches conducted show that the individual with dependent self-structure is sensitive to the interaction and this interaction affects the trust in and attitude towards the brand. Ultimately, the process results in emotional brand attachment.

In this context, companies must head towards gaining the trust of consumers. Companies need people who are emotionally attached to the brand to retain the customer for a long time in today's conditions. This need is met through the relationship of trust. To establish this connection, companies can both choose famous people trusted by society as a brand face and encourage the sharing of positive customer experiences. Consumer confidence will be kept alive and the foundations of brand attachment will be strengthened through word of mouth communication, which will be formed in this way. Also, the company's reflecting that it considers the wishes and expectations of its customers and asking for their ideas in the design process or the preparation phase of new products will be effective if the development of the positive emotions concerned. The key point here is the need to determine exactly what the elements that brands evaluate to create a positive attitude associate for the customer. In today's era of communication and technology, the most effective way to learn this is to use social media. It will be beneficial to use mutual communication that will be provided through virtual environments by also considering ethical rules not only to learn the customer's thoughts but also to guide their attitudes. Distribution of new products through sweepstakes to promote this process is considered to be one of the effective methods. Additionally, companies can have people who have gained the appreciation of the target audience and have succeeded in attracting their attention to advertise or recommend products. Likewise, they can get in contact with information channels, which the target audience uses the most and access the right people through the right channels. Briefly, companies should initially try working with celebrities that customers respect or those that the groups the customers are in like and follow and use opinion leaders effectively in this process. They should also use themes that can be approved by the target audience and the people around in the advertising or promotion process. In this way, they will address the personalities of the individuals and groups in question, will create positive attitudes and trust towards the brand by activating the interaction between individuals, and consequently will have developed emotional brand attachment. 


\section{REFERENCES}

Agrawal, N. and Maheswaran, D. (2005), The Effects of Self-Construal and Commitment on Persuasion. Journal of Consumer Research, 31(4), pp. 841-849.

Akgün, A. E., Koçoğlu, İ. and İmamoğlu, S. Z. (2013), An Emerging Consumer Experience: Emotional Branding. Procedia-Social and Behavioral Sciences, 99, pp. 503-508.

Alkailani, M. and Kumar, R. (2016), Impacting Innovativeness: The Role of Interpersonal Influences and Cultural Dimensions on Consumer Innovativeness, Journal of Strategic Innovation and Sustainability, 11(1), pp. 62-78.

Baldwin, M. W., Keelan, J. P. R., Fehr, B., Enns, V. and Koh-Rangarajoo, E. (1996). Social-Cognitive Conceptualization of Attachment Working Models: Availability and Accessibility Effects. Journal of Personality and Social Psychology, 71(1), pp. 94-109.

Bauer, H. H., Heinrich, D. and Martin, I. (2007), How To Create High Emotional Consumer-Brand Relationships? The Causalities of Brand Passion, Proceedings of The Australian and New Zealand Market Acad, University of Otago, pp. 2189-2198.

Başar, E. E. and Erciş, A. (2015), The Effect of Self-Construal on Statue and Role-Relaxed Consumption, Mediterranean Journal of Social Sciences, 6(3 S2), pp. 18-23.

Bearden, W. O., Netemeyer, R. G. and Teel, J. E. (1989), Measurement of Consumer Susceptibility to Interpersonal Influence, Journal of Consumer Research, 15(4), pp. 473-481.

Bouhlel, O., Mzoughi, N., Hadiji, D. and Slimane, I. B. (2011), Brand Personality's Influence on The Purchase Intention: A Mobile Marketing Case. International Journal of Business and Management, 6(9), pp. 210-227.

Chatterjee, S.C. and Chaudhuri, A. (2005), Are Trusted Brands Important?, Marketing Management Journal, 15 (1), pp. 1-16.

Chaudhuri, A. and Holbrook, M.B. (2001), The Chain of Effects From Brand Trust and Brand Affect to Brand Performance: The Role of Brand Loyalty, Journal of Marketing, 65, 2, pp. 81-93.

Chen, Q., Griffith, D. A. and Shen, F. (2005), The Effects of Interactivity on Cross-Channel Communication Effectiveness, Journal of Interactive Advertising, 5(2), pp. 19-28.

Chen, Y. S., Hung, S. T., Wang, T. Y., Huang, A. F. and Liao, Y. W. (2017), The Influence of Excessive Product Packaging on Green Brand Attachment: The Mediation Roles of Green Brand Attitude and Green Brand Image, Sustainability, 9, 654, pp. 1-15.

Cheong, A. L. H. (2013), An Exploration of Antecedents and Consequences of Brand Attachment Among A Cross Section of Malaysian Consumers, Asian Social Science, 9(5), pp. 263-273.

Chinomona, R. (2013), The Influence of Brand Experience on Brand Satisfaction, Trust and Attachment in South Africa, International Business \& Economics Research Journal (IBER), 12(10), pp. 1303-1316.

Chinomona, R. (2016), Brand Communication, Brand Image and Brand Trust As Antecedents of Brand Loyalty in Gauteng Province of South Africa, African Journal of Economic and Management Studies, 7(1), pp. 124-139.

Chung, J. Y., Lee, J. and Heath, R. L. (2013), Public Relations Aspects of Brand Attitudes and Customer Activity, Public Relations Review, 39(5), pp. 432-439.

Cross, S.E. and Madson, L. (1997), Models of The Self: Self-Construals and Gender, Psychological Bulletin, 122, pp. 5-37

Cross, S. E., Bacon, P. L. and Morris, M. L. (2000), The Relational-Interdependent Self-Construal and Relationships, Journal of Personality and Social Psychology, 78(4), pp. 791-808.

Berry, L. L. (2000), Cultivating Service Brand Equity, Journal of The Academy of Marketing Science, 28(1), pp. 128-137. 
Deniz, A. and Erciş, A. (2010), Kişilik Özellikleri, Hedonik ve Rasyonel Fayda, Marka Duygusu ve Marka Bağlılığı Arasındaki İlişkilerin Belirlenmesine Yönelik Bir Araştırma, Atatürk Üniversitesi İktisadi ve İdari Bilimler Dergisi, 24(2), pp. 141-165.

Deutsch, M. and Gerard, H. B. (1955), A Study of Normative and Informational Social Influences Upon İndividual Judgment, The Journal of Abnormal and Social Psychology, 51(3), pp. 629-636.

Doney, P.M., Barry, J. M. and Abratt, R. (2007), Trust Determinants and Outcomes in Global B2B Services, European Journal of Marketing. 41(9/10), pp. 1096-1116.

Escalas, J. E. and Bettman, J. R. (2005), Self-Construal, Reference Groups, and Brand Meaning, Journal of Consumer Research, 32(3), pp. 378-389.

Esch, F. R., Langner, T., Schmitt, B. H. and Geus, P. (2006), Are Brands Forever? How Brand Knowledge and Relationships Affect Current and Future Purchases, Journal of Product \& Brand Management, 15(2), pp. 98-105.

Eshghi, A., Sarkar, J. G. and Sarkar, A. (2017), Impact of Online Advertising on Adolescent's Brand Attitudes, Marketing Intelligence \& Planning, 35(6), pp. 706-723.

Fandos, C. and Flavian, C. (2006), Intrinsic and Extrinsic Quality Attributes, Loyalty and Buying Intention: An Analysis for A PDO Product, British Food Journal, 108(8), pp. 646-662.

Frasquet, M., Molla Descals, A. and Ruiz-Molina, M. E. (2017), Understanding Loyalty in Multichannel Retailing: The Role of Brand Trust and Brand Attachment, International Journal of Retail \& Distribution Management, 45(6), pp. 608-625.

Garbarino, E. and Johnson, M. S. (1999), The Different Roles of Satisfaction, Trust, and Commitment in Customer Relationships, Journal of Marketing, 63(2), pp. 70-87.

Gardner, W.L., Gabriel, S. and Lee, A.Y. (1999), “I” Value Freedom, But "We”" Value Relationships: Self-Construal Priming Mirrors Cultural Differences in Judgment, Psychological Science, 10, pp. 321326.

Girma, M. (2016), Exploring Consumers Footwear's Brand Preference and Its Antecedents between Age Groups and Gender: In Case of dire Dawa Administration, International Journal of Scientific and Research Publications, 6(6), pp. 2250-3153.

Göksu,T. (2007), Sosyal Psikoloji. Ankara. Seçkin Publishing.

Grisaffe, D. B. and Nguyen, H. P. (2011), Antecedents of Emotional Attachment to Brands, Journal of Business Research, 64(10), pp. 1052-1059.

Hair, F., Jr., Anderson, R. E., Tatham, R. L. and Black, W. C. (1998), Multivariate Data Analysis With Readings (5th ed.). Upper Saddle River, NJ: Prentice-Hall.

Hoffmann, A. O. and Broekhuizen, T. L. (2009), Susceptibility to and Impact of Interpersonal Influence in An Investment Context, Journal of The Academy of Marketing Science, 37(4), pp. 488-503.

Holland, R. W., Roeder, U. R., Rick B. van, B., Brandt, A. C. and Hannover, B. (2004), Don't Stand So Close To Me: The Effects of Self-Construal on Interpersonal Closeness, Psychological Science, 15(4), pp. 237-242.

Hoon Ang, S., Sim Cheng, P., Lim, E. A. and Kuan Tambyah, S. (2001), Spot The Difference: Consumer Responses Towards Counterfeits, Journal of consumer Marketing, 18(3), pp. 219-235.

Japutra, Arnold, Ekinci, Yuksel, and Simkin, Lyndon. (2014), Exploring Brand Attachment, Its Determinants and Outcomes, Journal of Strategic Marketing, 22(7), pp. 616-630.

Khare, A. (2014), Consumers' Susceptibility to Interpersonal Influence As A Determining Factor of Ecologically Conscious Behaviour, Marketing Intelligence \& Planning, 32(1), pp. 2-20.

Krohmer, H., Malär, L., Hoyer, W. and Nyffenegger, B. (2009), The Fit Between Brand Personality and Consumer's Self: The Importance of Actual Versus Ideal Self For Brand Performance. In AMA Winter Educators' Conference Proceedings, 20, pp. 412-413. 
Kropp, F., Lavack, A. M. and Silvera, D. H. (2003), Values And Collective Self-Esteem As Predictors of Consumer Susceptibility to Interpersonal Influence Among University Students, International Marketing Review, 22(1), pp. 7-33.

Lau, G. T. and Lee, S. H. (1999), Consumers' Trust in A Brand and The Link to Brand Loyalty, Journal of Market-Focused Management, 4(4), pp. 341-370.

Levy, S. and Hino, H. (2016), Emotional Brand Attachment: A Factor in Customer-Bank Relationships, International Journal of Bank Marketing, 34(2), pp. 136-150.

Malär, L., Krohmer, H., Hoyer, W. D. and Nyffenegger, B. (2011), Emotional Brand Attachment and Brand Personality: The Relative Importance of The Actual and The Ideal Self, Journal of Marketing, 75(4), pp. 35-52.

Markus, H. R. and Kitayama, S. (1991), Culture And The Self: Implications For Cognition, Emotion, and Motivation. Psychological Review, 98, pp. 224-253.

McAllister, D. J. (1995), Affect-and Cognition-Based Trust As Foundations for Interpersonal Cooperation in Organizations, Academy Of Management Journal, 38(1), pp. 24-59.

Miller, R. S. (1997), Inattentive and Contented: Relationship Commitment and Attention to Alternatives. Journal of Personality and Social Psychology, 73, pp. 758-766.

Mitchell, A. A. and Olson, J. C. (1981), Are Product Attribute Beliefs The Only Mediator of Advertising Effects on Brand Attitude?, Journal of Marketing Research, 18(3), pp. 318-332.

Mourali, M., Laroche, M. and Pons, F. (2005), Individualistic Orientation and Consumer Susceptibility to Interpersonal Influence, Journal of Services Marketing. 19(3), pp. 164-173.

Nakip, M. (2006), Pazarlama Araştırmaları. Seçkin Publishing.

Pourazad, N. and Pare, V. (2014), Emotional Brand Attachment: Antecedents and Consequences for Luxury Brands. In 28th Australian And New Zealand Academy of Management Conference, pp. 1-43.

Richins, M. L. (1994), Special Possessions and The Expression of Material Values, Journal of Consumer Research, 21, pp. 522-533.

Sağlam, M. and Sağlam, B. Ç. (2016), Marka Güveni ve Marka Bağlılığının Satın Alma Niyeti Üzerine Etkisi: Akıllı Telefon Pazarında Bir Araştırma, Journal of Research in Business \& Social Science, 5(5), pp. 34-43.

Saleem, A. and Ellahi, A. (2017), Influence of Electronic Word of Mouth on Purchase Intention of Fashion Products in Social Networking Websites, Pakistan Journal of Commerce and Social Sciences (PJCSS), 11(2), pp. 597-622.

Shen, Y. C., Huang, C. Y., Chu, C. H. and Liao, H. C. (2010), Virtual Community Loyalty: An Interpersonal-Interaction Perspective, International Journal of Electronic Commerce, 15(1), pp. 49-74.

Shiong, P.K. (2019), Investigating Tourist's Behavioral Intentions Using Stimulus-Organism Response Theory . http://eprints.utar.edu.my/3461/1/fyp_PR_2019_KWX.pdf Date Accessed: 23.09.2019

Singelis, T. M. (1994), The Measurement of Independent and Interdependent Self-Construal,. Personality and Social Psychology Bulletin, 20(5), pp. 580-591.

Sukhu, A., Choi, H., Bujisic, M. and Bilgihan, A. (2019), Satisfaction and Positive Emotions: A Comparison of The Influence of Hotel Guests' Beliefs And Attitudes on Their Satisfaction and Emotions. International Journal of Hospitality Management, 77, pp. 51-63.

Sun, T., Tai, Z. and Tsai, K. C. (2009), The Role of Interdependent Self-Construal in Consumers'susceptibility to Retail Salespersons' Influence: A Hierarchical Approach, Journal of Retailing and Consumer services, 16 (5), pp. 360-366.

Thomson, M., MacInnis, D. J. and Park, C. W. (2005), The Ties That Bind: Measuring The Strength of Consumers' Emotional Attachments to Brands, Journal of Consumer Psychology, 15(1), pp. 77-91.

Thurasamy, R., Mohamad, O., Jantan, M., Chow, J. L. W. and Nasirin, S. (2002). Counterfeit Music Cds: Social and Personality Influences, Demographics, Attitudes and Purchase Intention: Some Insights From 
Malaysia. In The Proceedings of The 2nd European Conference on Research Methods in Business and Management, Reading University, Uk, 20-21 March 2003, Pp. 329-336.

Uddin, S. F. and Khan, M. N. (2018), Young Consumer's Green Purchasing Behavior: Opportunities for Green Marketing, Journal of Global Marketing, 31(4), pp. 270-281.

Ulusu, Y. (2011), Marka İmajının Marka Güvenine Etkisi, Journal of Yasar University, 24(6), pp. 39323950.

Wang, F., Zhang, H., Zang, H. and Ouyang, M. (2005), Purchasing Pirated Software: An Initial Examination of Chinese Consumers, Journal of Consumer Marketing, 22(6), pp. 340-351.

Webber, A. M. (1997), What Great Brands Do An Interview of Scott Bedbury.

https://www.fastcompany.com/29056/what-great-brands-do Date Accessed: 14.11.2019.

Vlachos, Pavlos A, Theotokis, Aristeidis, Pramatari, Katerina, and Vrechopoulos, Adam. (2010),

Consumer-Retailer Emotional Attachment: Some Antecedents and The Moderating Role of Attachment Anxiety. European Journal of Marketing, 44(9/10), pp. 1478-1499.

Zarolia, P., Weisbuch, M. and McRae, K. (2017), Influence of Indirect Information on Interpersonal Trust Despite Direct Information, Journal of Personality and Social Psychology, 112(1), pp. 39-57 